\title{
TROSKA CHRYSTUSA O GRZESZNY KOŚCIÓŁ W KOMENTARZU DO KSIĘGI SOFONIASZA ŚW. HIERONIMA
}

Komentarz Hieronima do Księgi Sofoniasza powstał w ramach prac nad pozostałymi prorokami mniejszymi w latach 389-392. Napisany został na Bliskim Wschodzie, po opuszczeniu przez Hieronima Rzymu i rozpoczęciu życia cenobitycznego w Betlejem. Jest to okres szczególnej fascynacji kwestiami natury filologicznej oraz historyczno-geograficznym kontekstem Ziemi Świętej. Wtedy też pisze on dzieła zawierające wyjaśnienia nazw hebrajskich oraz prowadzi prace oparte na Orygenesowskej Heksapli, porównując tekst hebrajski z tłumaczeniami Septuaginty, Akwili, Symmacha i Teodocjona. To wszystko znajduje swe odbicie w komentarzu do Sofoniasza, gdzie po tłumaczeniu tekstu hebrajskiego Hieronim zamieszcza przekład Septuaginty, zaś w ramach dyskusji nad specyfiką poszczególnych tekstów, przywołuje również innych tłumaczy, zwłaszcza Symmacha (8 razy). ${ }^{65}$

Po analizie filologicznej, którą Hieronim nazywa interpretacją literalną lub historyczną, przechodzi do interpretacji teologicznej. ${ }^{66}$ Zauważa się w tym względzie wpływy Orygenesa, z którego zagi-

${ }^{65} \mathrm{Na}$ temat metody stosowanej przez Hieronima w zakresie komentarystyki biblijnej zob. P. S i n i s c a $1 \mathrm{c}$ o, La teoria e la tecnica del commentario biblico secondo Girolamo, Annali di Storia dell’Esegesi 5/1988, s. 225-238. W szczególności w odniesieniu do dwunastu proroków mniejszych zob. A. S t a u b, Die Egzegetische Metode des Hieronymus im Kommentar zum Zwölfprophetenbuch, diss. Pont. Ath. S. Anselmo, Uznach 1978.

66 Szerzej na temat egzegezy biblijnej Hieronima zob. D. B r o w n, Vir Trilinguis. A Study in the Biblical Exegesis of st. Jerome, Kampen 1992; W. H a g e m a n n, Wort als Begegnung mit Christus. Die christozentrische Schriftsauslegung des Kirchenvaters Hieronymus, Trierer Theologische Studien 23, Trier 1970; P. J a y, 
nionych komentarzy do proroków mniejszych mógł korzystać. Należy pamiętać, że spory Orygenesowe wybuchają na Wschodzie ze szczególnym nasileniem dopiero po 393 r. Zatem w okresie, w którym Hieronim tworzy swoje dzieło, postrzega jego myśl jako ważny i inspirujący wkład w chrześcijańską tradycję interpretacji Biblii.

$\mathrm{O}$ wiele jednak silniejszy wydaje się wpływ na myśl teologiczną Hieronima resentymentów związanych z burzliwym doświadczeniem konfliktów wewnątrzkościelnych po śmierci papieża Damazego, które pośrednio wpłynęły na decyzję, by opuścić Rzym i udać się do Ziemi Świętej. Niechęć, by nie powiedzieć wrogość, z jaką Strydonita spotkał się w Rzymie po śmierci Damazego, któremu służył jako sekretarz i doradca, jak również nieporozumienia w relacjach z odmiennymi kulturowo hierarchami greckojęzycznych wspólnot kościoła bizantyjskiego, stanowią tło refleksji eklezjologicznej, jaką znajdujemy w komentarzu do Sofoniasza.

Refleksja ta idzie w dwóch kierunkach. Po pierwsze, aktualizując zarzuty, jakie prorok czyni pod adresem Jerozolimy oraz kapłanów starożytnego Izraela, odnosząc je do Kościoła i jego hierarchii. To odniesienie czasami ma charakter eschatologiczny, jednak nawet wówczas nietrudno odnieść wrażenie, że Hieronim ma przed oczyma sytuację Kościoła mu współczesnego. Drugi kierunek to aktualizacja oczyszczających działań, jakie w kontekście historycznym Bóg podejmuje w odniesieniu do Izraela, by go odnowić i nawrócić ku sobie. Hieronim odnosi je do działań Chrystusa wobec Kościoła, które również mają na celu jego oczyszczenie i uświęcenie. Także w tym względzie perspektywa eschatologiczna łączy się z aktualizacją tekstu biblijnego. W swojej interpretacji Hieronim posługuje się przede wszystkim metodą alegoryczno-symboliczną ${ }^{67}$

L'exégese de Saint Jérôme d'après son „Commentaire sur Isaïe”, Études Augustiniennes, Paris 1985; A. P e n n a, Principi e carattere dell'esegesi di S. Girolamo, Roma 1950.

${ }^{67}$ Szerzej na temat tej metody zob. K. B a r d s k i, Stowo oczyma gołębicy. Metoda symboliczno-alegorycznej interpretacji Biblii oraz jej teologiczne i duszpasterskie zastosowanie, Rozprawy Naukowe 3, Warszawa 2007; t e n ż e, Lektyka 


\section{Grzechy Kościoła}

Próżna chwała i fałszywa godność kapłanów i biskupów (So 1,4)

Wśród gróźb wypowiedzianych przez Sofoniasza pod adresem Jerozolimy i kapłanów pełniących posługę w świątyni, rozbrzmiewają słowa: „Wyciągnę rękę przeciwko Judzie, i przeciw wszystkim mieszkańcom Jeruzalem; i wytępię z tego miejsca pozostałości Baala, i imiona sług bałwochwalczych wraz z kapłanami” (So 1,4). Swoją aktualizację Hieronim rozpoczyna od etymologii słowa Baal. Powołuje się na przekład Septuaginty, który w rękopiśmiennej tradycji antiocheńskiej w tym miejscu używa liczby mnogiej Baalim, co nasz autor tłumaczy in sublimioribus (,,w tych rzeczach, które są położone wysoko"), odczytując nazwę kananejskiego bóstwa jako przyimek $b^{e}($, w”) i rzeczownik od czasownika '-l- $h$ (,wznosić się ku górze”). „To, co położone wysoko”, to oczywiście w znaczeniu przenośnym ludzka pycha i wyniosłość, dlatego też Strydonita zaraz dodaje: „Pan usunie imiona próżnej chwały i fałszywej godności, które przebywają w Kościele". ${ }^{68}$

Następnie rozwija tę myśl, powołując się na zasadzie skojarzenia reminiscencyjnego na Jk 2,2-3: „Gdyby przyszedł na wasze zgromadzenie człowiek przystrojony w złote pierścienie i bogatą szatę i przybył także człowiek ubogi w zabrudzonej szacie, a wy spojrzycie na bogato odzianego i powiecie: «Usiądź na zaszczytnym miejscu!», do ubogiego zaś powiecie: «Stań sobie tam albo usiądź u podnóżka mojego!», to czy nie czynicie różnic między sobą i nie stajecie się sędziami przewrotnymi?" Cytat z Listu Jakuba zostaje odniesiony do kapłanów i biskupów, to oni są tymi przystrojonymi w złote pierścienie i bogate szaty, podczas gdy człowiek święty, lecz ubogi, nie może znaleźć wśród nich miejsca. W rezultacie jednak Pan

Salomona. Biblia-Symbol-Interpretacja, Rozprawy Naukowe 6, Warszawa 2011; t e n ż e, Alegoryczno-symboliczna interpretacja Biblii, Kraków 2016.

${ }^{68}$ „Auferet autem Dominus nomina vanae gloriae et admirationis falsae, quae versantur in Ecclesia"; In Sof., ad 1,4-6; CCL 76A,662. 
usunie grzeszników „wraz z kapłanami, którzy na próżno chełpią się tytułem biskupa i godnością kapłaństwa hierarchicznego a nie tym, co czynią". 69

\section{Porzucenie szaty Chrystusa (So 1,8)}

Kolejny werset stanowiący punkt wyjścia dla Hieronimowej aktualizacji tekstu biblijnego to So 1,8: ,Ja ześlę karę na książąt i synów królewskich, i wszystkich, którzy się ubierają w szaty cudzoziemskie". Tym razem odniesienie alegoryczne dotyczy nie tylko hierarchii („,na książąat i synów królewskich”), ale każdego chrześcijanina (,i wszystkich”), którego mogą dotyczyć te słowa.

Podobnie jak w przypadku omówionym we wcześniejszym punkcie, pomostem łączącym tekst Sofoniasza z sytuacją współczesną komentatorowi są połączone w jedno cytaty z Nowego Testamentu, tym razem z Listów do Rzymian (,przyobleczcie się w Pana Jezusa Chrystusa” - Rz 13,14) i do Kolosan („obleczcie się w serdeczne miłosierdzie, dobroć, pokorę, cichość, cierpliwość" - Kol 2,12). Hieronim odwołuje się do symboliki szaty, która zresztą obecna jest już na poziomie sensu historycznego. O ile jednak Sofoniasz, używając obrazu „cudzoziemskiej szaty” miał na myśli porzucenie wierności jedynemu Bogu i naśladowanie obyczajów ludów ościennych, to Hieronim dopatruje się tu porzucenia szaty Chrystusa, by przyoblec się w szatę grzechu: „Szaty cudzoziemskie i wszystko, co następuje, odnosimy do każdego wierzącego, który wprawdzie powinien odziać się w Chrystusa i zwracać ku temu, co wewnątrz, lecz ubiera się w szaty różnorakich grzechów". ${ }^{70}$

69 „Cum sacerdotibus qui frustra sibi applaudunt in episcopali nomine, et in presbyterii dignitate, et non in opere"; tamże.

70 „Indumenta quoque aliena, et omnia quae sequuntur, referamus ad unumquemque credentium, qui cum debuerant induti esse Christo, et semper versari intrinsecus, variis se peccatorum operuerunt vestimentis"; In Sof, ad 1,8-9; CCL 665. 


\section{Zlekceważenie chrztu i pokuty (So 1,10)}

Werset So 1,10 jest głęboko osadzony w realiach geograficznych starożytnej Jerozolimy: „I będzie owego dnia - wyrocznia Pana głośne wołanie od Bramy Rybnej, i lament z drugiej strony miasta oraz trzask wielki od strony pagórków”. Hebrajskie wyrażenie mîn hammîšnê (,z drugiej”) nie wskazuje jednoznacznie, że chodzi o „drugą stronę miasta”, jak to interpretuje Biblia Tysiąclecia i wiele współczesnych przekładów. Dlatego w tłumaczeniu Hieronima czytamy: „I będzie owego dnia - mówi Pan - głośne wołanie od Bramy Rybnej, i lament od drugiej oraz ucisk wielki od strony pagórków". ${ }^{71}$

W przekładzie Hieronima pojawia się zatem wizja dwóch bram prowadzących do Jerozolimy. Opierając się na symbolice Jerozolima - Kościół i na zasadzie skojarzenia oglądowego, Strydonita łączy motywy dwóch bram z dwoma sakramentami, dzięki którym człowiek wchodzi (bądź wraca) do Kościoła. Pierwszym jest oczywiście chrzest (udzielany łącznie z bierzmowaniem), który symbolizuje Brama Rybna, drugim zaś pojednanie, zwane w starożytności poenitentia secunda (,druga pokuta”), udzielane według ówczesnej praktyki jednokrotnie, po wypełnieniu przepisanej kanonami pokuty. Oba te ryty (pamiętajmy, że w czasach Hieronima nie używano terminu „sakrament” w odniesieniu do rytów pokuty i pojednania) służyły wejściu lub powrotowi do Kościoła, podobnie jak przez bramę wchodzi się do wnętrza miasta. ${ }^{72}$

W interesujący sposób Hieronim aktualizuje alegorię. Czas przyszły („,będzie wołanie i lament”) odnosi do czasów eschatologicznych. To wówczas, przy końcu świata będzie lament od Bramy Rybnej i od bramy „drugiej”, to znaczy rozpacz z powodu zaniedbywania na

${ }^{71}$, „Et erit in die illa dicit Dominus vox clamoris a porta Piscium et ululatus a secunda"; In Sof., ad 1,10; CCL 666. Tłumaczenie zamieszczone w tym miejscu komentarza Hieronima pokrywa się z przekładem Wulgaty.

72 Por. „Per has enim duas portas baptismi et paenitentiae in Hierusalem, id est, in Ecclesiam Dei vel introitus vel reditus est"; In Sof., ad 1,10; CCL 667. 
przestrzeni dziejów Kościoła rytów inicjacji chrześcijańskiej (chrzest i bierzmowanie) oraz rytu pokuty i pojednania. ${ }^{73}$

Ucisk z powodu błędnych doktryn (So 1,11; 2,8)

Przynajmniej dwa odniesienia symboliczne obrazują w interpretacji Hieronima błędne doktryny zagrażające jedności Kościoła. Pierwsze znajdujemy w So 1,11: „Narzekajcie, mieszkańcy Moździerza, bo wytępiony będzie cały lud Kanaanu; wygładzeni zostaną wszyscy, którzy odważają srebro". W tym miejscu jednak Hieronim odwołuje się do tłumaczenia Septuaginty, gdzie hebrajskie maktēš („moździerz”) zostało przełożone katakekommenē, czyli „poćwiartowana” lub „rozdrobniona”. Tą „poćwiatrowaną” jest w oczach Hieronima Kościół (rodzaj żeński w licznych interpretacjach odnoszony był do Kościoła) podzielony na skutek błędnych doktryn głoszonych przez heretyków. ${ }^{74}$

Drugi obraz wyłania się ze słów Sofoniasza: „Słyszałem urąganie Moabu i bluźnierstwa synów Ammona, którymi lżyli mój lud i wywyższali się w swoich granicach" (So 2,8). Częstokroć w symbolice starożytnego chrześcijaństwa ludy otaczające starożytny Izrael interpretowane były jako innowiercy, którzy otaczają i zwalczają Kościół. Również tym wersecie Moab i Ammon stają się w interpretacji Hieronima obrazem heretyków atakujących jasność i prostotę prawowiernej nauki za pomocą dialektyki, retoryki i wszelkich sofizmatów. ${ }^{75}$

73 Por. „Vel certe in fine mundi et in consummatione lugebunt a porta piscium prima, qui suum baptisma non servaverunt; lugebunt a secunda, qui non egerunt pro peccatis dignam poenitentiam"; tamże.

74 „Ecclesia, quae schismatibus, haeresibusque lacerata est, et ad singula vulnera plangit filios interfectos"; In Sof., ad 1,11; CCL 668.

75 „Vide haereticos in dialectica sibi et rhetorica et omnium sophismatum dogmatibus applaudentes, contemnere Ecclesiae rusticitatem"; In Sof., ad 2,8-11; CCL 686. 
Grzechy ludzi Kościoła (So 2,9)

Prorok Sofoniasz w kolejnym wersecie dodaje: „Dlatego: Na moje życie - wyrocznia Pana Zastępów, Boga Izraela: Moab będzie jak Sodoma, a synowie Ammona jak Gomora" (So 2,9). O ile Moab i Ammon, jako krainy położone poza Ziemią Obiecaną, w wyobraźni starożytnych chrześcijan symbolizowały innowierców, to Sodoma i Gomora, jako miasta leżące po zachodniej stronie Morza Martwego, oznaczały tych, którzy należą do Kościoła, lecz dopuszczają się szczególnie odrażających zbrodni.

To właśnie do mieszkańców Sodomy i Gomory przyrównuje Hieronim tych, którzy piastują urzędy kościelne (ad ecclesiasticos) oraz postępują jak starcy pragnący zgwałcić Zuzannę, oznaczającą Kościół. Zauważmy subtelną aluzję opartą na dwuznaczności greckiego terminu presbyter, jaka kryje się w słowach Strydonity, gdy groźby Sofoniasza kieruje ad presbyteros cupientes sub figura Susannae Ecclesiae corrumpere castitatem ${ }^{76}$ („do starców/prezbiterów pragnących pod postacią Zuzanny splugawić czystość Kościoła”).

Fałszywi chrześcijanie wewnątrz Kościoła (So 2,14)

Hieronim zatem piętnuje nie tylko błędne nauki innowierców, pozostających poza wspólnotą eklezjalną, lecz również dostrzega fałsz wewnątrz Kościoła. W ten sposób Sofoniasz opisuje ruiny Jerozolimy: „I będą się wylegiwać w jej obrębie stada, wszelkie rodzaje zwierząt: tak pelikan, jak jeż zanocują na głowicach jej kolumn" (So 2,14). O ile hebrajskie qippor jednoznacznie wskazuje na jeża, to rzeczownik $q \bar{a}$ 'at ma niejasne znaczenie. We współczesnych przekładach często jest utożsamiany z pelikanem, jednak Septuaginta interpretuje to zwierzę jako chamaileo, czyli kameleona. I na takim właśnie znaczeniu Hieronim buduje swoją interpretację.

Zarówno kameleon, jak i jeż budzą wyraziste skojarzenia. Pierwszy z nich, którego cechą szczególną jest umiejętność zmiany koloru

76 In Sof, ad 2,8-11; CCL 687. 
skóry, oznacza ludzi fałszywych, którzy z jednego grzechu przechodzą w drugi, natomiast jeż, z powodu swoich kolców, symbolizuje tych, którzy ranią każdego, kto się do nich zbliży. ${ }^{77}$ Zarówno jedno, jak i drugie zwierzę zamieszkuje w ruinach Jerozolimy, a więc oznacza grzeszników, którzy, dopuszczając się zła, pozostają we wnętrzu Kościoła.

\section{Ucisk podwładnych przez przełożonych (So 3,3)}

Sofoniasz kieruje ostrze swojej krytyki szczególnie przeciwko uprzywilejowanym warstwom starożytnego Izraela: ,Jego książęta są pośród niego lwami ryczącymi, sędziowie jego - wieczorem wilkami, które nic do rana nie pozostawiają" (So 3,3). W literackiej formie paralelizmu synonimicznego (książęta - sędziowie, lwy - wilki) prorok piętnuje postawę zarządzających Izraelem, przyrównując ich do zwierząt drapieżnych, które w innych miejscach Biblii przyjmują negatywne znaczenie metaforyczne. ${ }^{78}$ Dramatyzmu wersetowi dodaje obraz nocy, czyli czasu ciemności, podczas której niszczycielska działalność wilków (niegodziwych sędziów) osiąga swój zenit.

Zarówno książęta, jak i sędziowie z Sofoniaszowej wyroczni symbolizują dla Hieronima przełożonych Kościoła, a więc biskupów i kapłanów. W sposób wyrazisty Strydonita pisze o tych, którzy powinni być pasterzami trzody, a w rzeczywistości są drapieżnymi lwami, które ryczą głosem tyranów i wściekłymi obelgami miażdżą lud. ${ }^{79}$ Natomiast sędziowie starożytnego Izraela, przyrównani do wilków, obrazują tych spośród przełożonych Kościoła, którzy dobra eklezjalne

77 „Chamaeleontes qui non habent unum colorem; sed diversis peccatis, nunc avaritia, nunc luxuria, nunc crudelitate, nunc libidine, nunc tristitia, nunc exsultatione per momenta mutantur. Et hericii in praesepibus eorum, animal spinosum et plenum sentibus, et vulnerans quidquid contigerit"; In Sof., ad 2,12-15; CCL 693.

78 Na temat lwów zob. Jr 2,15; 50,17; 51,38; Ps 35,17; passim. Na temat wilków zob. Ez 22,27; Ha 1,8; Mt 10,16; Łk 10,3; Dz 20,29, passim.

79 „Viderimus principes eius ita in subjectos populos detonare, et voce tyrannica rabidisque conviciis plebem conterere, ut non pastorem in grege, sed leonem inter oviculas putes frendere"; In Sof., ad 3,1-7; CCL 696. 
wykorzystują dla własnych zysków, złożone ofiary przeznaczają na życie w luksusie $\mathrm{i}$ - na podobieństwo żarłocznych wilków - nie dzielą się niczym z wiernymi cierpiącymi niedostatek. ${ }^{80}$

\section{Uczeni Kościoła, którzy lekceważą Ducha Świętego i dobroć Boga (So 3,4a)}

Słowa Sofoniasza, dotyczące proroków: „Prorocy jego są lekkomyślni - mężowie wiarołomni” (So 3,4a), Hieronim odnosi do uczonych Kościoła, którzy - podobnie jak starożytni prorocy w Izraelu - winni być w Kościele „nosicielami Ducha” (pneumatoforoi). Co ciekawe, nie odnosi tych słów jedynie do fałszywych proroków, ale do tych, którzy mają świadomość tego, czego Bóg od nich oczekuje. Zostali oni autentycznie napełnieni Duchem Świętym (doctores qui sancto Spiritu pleni fuerant) i rzeczywiście poznali, czym jest dobroć Boga (noverint multam bonitatem ejus), a jednak zlekceważyli te dary i zamiast doświadczyć Bożego miłosierdzia, gromadzą dla siebie jak w skarbcu Jego gniew (contemnant divitias bonitatis ejus thesaurizantes sibi iram) ${ }^{81}$

Zapewne Hieronim ma w tym miejscu na myśli znanych mu osobiście hierarchów lub prezbiterów, piastujących godności kościelne i mających odpowiednie wykształcenie, którym jednak zarzuca dwa podstawowe grzechy: pychę i pogardę. ${ }^{82}$ Strydonita nie kwestionuje samego faktu piastowania urzędu kościelnego, co więcej, przytacza nawet 1Tm 3,1 („,Jeśli ktoś dąży do biskupstwa, pożąda dobrego zadania”), jednak podkreśla w tym wersecie słowo „zadanie” (opus), przeciwstawiając je ,godności” (dignitas). Jeśli więc ktoś przyjmuje biskupstwo ze względu na godność, a nie zobowiązania do pod-

${ }^{80}$ „Possessiunculas Ecclesiae, et ea quae in Dei donaria conferuntur, vertentes in lucrum suum, ut non habeant pauperes quod mane comedant, qui quasi in nocte, et nullo vidente, omnia populantur; et cum luporum more cuncta diripiant, ne parvos quidem cibos indigentibus derelinquunt"; tamże.

81 In Sof., ad 3,1-7; CCL 699.

82 „Frequenter soleat superbiae in Dominum et contemptus existere”; tamże. 
jęcia odpowiedzialnych zadań (despecto opere, solam aspexerit dignitatem), ${ }^{83}$ wówczas staje się adresatem Sofoniaszowej krytyki.

\section{Troska Chrystusa o Kościół}

Światło słowa i rozsądku (So 1,12)

Wobec grzechów popełnianych przez ludzi Kościoła, Jezus nie pozostaje bezczynny. Przybywa, by oczyścić, odnowić i przywrócić piękno swojej Oblubienicy. Sofoniasz w ten sposób zapowiada przybycie Boga, który niesie światło: „Wówczas tak będzie: z pochodniami przeszukam Jeruzalem" (So 1,12). Te słowa Hieronim odnosi do czasów ostatecznych: „Przy końcu świata, gdyż tak rozumiany jest Dzień Pański, Pan przeszuka Jeruzalem, to znaczy swój Kościół z pochodnią". ${ }^{84}$ Pochodnia przywodzi na myśl skojarzenie ze światłem, które w tradycji chrześcijańskiej ma bogatą symbolikę. Przede wszystkim odnosi się do samego Chrystusa (,Ja jestem światłością świata" - J 8,12), może jednak oznaczać również inne rzeczywistości. Hieronim wyjaśnia w swoim komentarzu: „Wówczas Pan przeszuka wszystkie wady Jeruzalem przy pomocy swojego słowa oraz roztropności". ${ }^{85}$ Symbolika światła jest obecna w tradycji biblijnej zarówno w odniesieniu do słowa Bożego (Prz 6,23; Ps 119,105), jak i mądrości (Ko 2,13; Dn 5,14), ponadto warto zauważyć, że działanie Boga określone jako „przeszukiwanie” oznacza nie tyle sąd i karę, ile raczej uświadomienie, upomnienie, wydobycie na jaw (paralelnie do czasownika pāqad użytego w drugim stychu wersetu ${ }^{86}$ ), by zachęcić

83 In Sof., ad 3,1-7; CCL 700 (na końcu).

84 „In consummatione autem mundi, quia dies Domini ipsa intelligitur, scrutabitur Dominus Hierusalem, id est Ecclesiam suam cum lucerna”; In Sof., ad 1,12; CCL 670.

${ }^{85}$ „Tunc in lucerna sermonis sui atque rationis omnia vitia scrutabitur Dominus in Jerusalem"; tamże.

${ }^{86}$ Szerzej na temat teologicznych implikacji czasownika zob. K. B a r d s k i, Pequddah i episkope: w poszukiwaniu biblijnej terminologii dla Bożej Opatrzności, Warszawskie Studia Teologiczne 19/2006, s. 65-82. 
do nawrócenia. Hieronim czyni wyraźne rozróżnienie pomiędzy peccatores (grzesznicy), którzy zawsze mają szansę doświadczyć Bożego miłosierdzia a contemptores (ci, którzy gardzą), ${ }^{87}$ którzy niejako zamykają przed Nim swoje serca.

\section{Zburzenie przewrotnych konstrukcji (So 1,13)}

Kolejny werset przedstawia bezowocność działań ludzi przewrotnych w Izraelu, która w pełni okaże się w dniu Pańskim. Została ona zobrazowana na przykładzie domów i winnic: „Majętność ich będzie na łup wydana, a domy ich - na spustoszenie, i zbudują domy, lecz nie będą mieszkali; zasadzą także winnice, ale nie będą pili z nich wina" (So 1,13). Hieronim interpretuje to zdanie alegorycznie w następujący sposób: „Dom jego na spustoszenie, wielu jest bowiem takich w Kościele, którzy na krwi budują Syjon a Jeruzalem na niegodziwości, dla nich korzystne będzie zburzenie takich domów" ${ }^{88}$

Wprawdzie tekst Sofoniasza nie mówi nic o zburzeniu domu a jedynie o pozostawieniu go niezamieszkanym, jednak wydaje się, że Hieronim rozszerza myśl proroka, przywołując reminiscencyjnie Koheleta 3,2-3: ,Jest czas rodzenia i czas umierania, czas sadzenia i czas wyrywania tego, co zasadzono, czas zabijania i czas leczenia, czas burzenia i czas budowania”. W chrześcijańskiej tradycji interpretacyjnej słowa te były często odnoszone do czasów ostatecznych. ${ }^{89} \mathrm{~W}$ parafrazie Hieronimowej wydają się jednak zyskiwać szersze znaczenie: „Zła budowla zostanie zburzona, aby następnie została wzniesiona dobra budowla; przewrotna roślinność zostanie wykorzeniona, aby

87 „Fiet judicium et vindicta, non in peccatores (poterat enim et peccatum veniam promereri), sed in contemptores"; In Sof., ad 1,12; CCL 670.

88 „Et domus eorum in desertum, multi sunt in Ecclesia aedificantes Sion in sanguine, et Hierusalem in iniquitate, quibus prodest tales domus destru"; In Sof., ad 1,13-14; CCL 671.

89 Zob. K. B a rd s k i, Poemat o czasie wtaściwym (Koh 3,1-8) w starożytnej interpretacji judaistycznej i chrześcijańskiej, w: W. C h r o s t o w s k i (red.), „Jak śmierć potężna jest miłość" (Pnp 8,6). Księga pamiątkowa ku czci Księdza Profesora Juliana Warzechy SAC (1944-2009), Apostolicum, Ząbki 2009, s. 25-32. 
została zasadzona dobra roślinność" ${ }^{90}$ Swoją interpretację Hieronim sytuuje w kontekście eschatologicznym: wszystko to, co w Kościele zostało zbudowane na krzywdzie ludzkiej, zostanie zburzone i wykorzenione, natomiast sam Bóg wzniesie w tym miejscu „dobrą budowlę” i zasadzi „dobrą roślinność”. Co więcej, zniszczenie i ruina niegodziwych konstrukcji człowieka przewrotnego paradoksalnie przyniesie mu korzyść w perspektywie eschatologicznej.

Zaproszenie do jedności Kościoła w miłości i pokoju (So 2,1)

Sofoniaszowe słowa zachęty: „Zbierzcie się! Zgromadźcie się! narodzie bez wstydu" (So 2,1), Hieronim adresuje do chrześcijan, którzy nie chcą poddać się karności i gardzą Bożymi przykazaniami. Kościół ma być miejscem zgromadzenia: „Zgromadźcie się w Kościele, połączcie się ze sobą miłością i pokojem". ${ }^{91}$

Jedność Kościoła wydaje się w tym kontekście szczególną kategorią, na którą Hieronim kładzie nacisk. Zgodnie ze słowami Jezusa, podstawowym spojeniem warunkującym tę jedność jest „wzajemna miłość" (J 13,34-35; 15,17; 1Tes 4,9; 1J 3,11.23), natomiast z perspektywy karności (disciplina) kościelnej na pierwszy plan wysuwa się pokój. Sformułowania „udzielanie pokoju”, „przyjmowanie pokoju” itp. należały do terminologii pokutnej. Grzesznicy po odbyciu przepisanej pokuty kanonicznej byli we Wigilię Paschalną przyjmowani do „pokoju Kościoła” ( pax Ecclesiae). Dlatego w tym właśnie kierunku zwrócona jest aktualizująca interpretacja Hieronima, która z perspektywy eschatologicznej wydobywa wnioski dotyczące wezwania do aktualnego nawrócenia i pokuty każdego chrześcijanina, z zwłaszcza grzesznika zobowiązanego do odbycia pokuty: „Zbierzcie się, zgromadźcie się, póki nie nadszedł czas sądu i nie przeminęła cała

90 „Destruitur aedificatio pessima, ut postea aedificatio bona construatur: eradicatur iniqua plantatio, ut plantatio justa ponatur"; In Sof., ad 1,13-14; CCL 671.

91 „Convenite in Ecclesiam, sociamini vobis charitate et pace”; In Sof., ad 2,1-2; CCL 677. 
wasza chwała. Wtedy będziecie chcieli czynić pokutę, gdy nie będzie miejsca na pokutę, lecz na karę". ${ }^{2}$

Reszta - znający słowo Boże (So 2,9)

Niegodziwy Moab zostanie w myśl słów Sofoniasza pokonany przez resztę Izraela: „Reszta ludu mego ich złupi, a pozostali z mego narodu przejmą ich posiadłości” (So 2,9). Z perspektywy starotestamentalnej prorok odwołuje się do pojęcia „reszty [še’ār] Izraela”, która wyrażała myśl, że mimo niewierności i grzechów popełnianych przez wielu przedstawicieli narodu wybranego, Bóg zachowuje swoją wierność obietnicom ze względu na niewielką liczbę Izraelitów wiernych przymierzu.

Pojęcie „reszta Izraela” Hieronim odnosi do Kościoła, gdy w kontekście przewrotności i grzechów popełnianych przez hierarchów, pisze o ,pozostałych z ludu Bożego, to znaczy ludziach Kościoła wykształconych w Piśmie Pana, którzy ich ograbią". ${ }^{93}$ W ujęciu Hieronima zatem, resztą Kościoła, której przypadną prawdziwe godności i prawdziwa chwała, są ludzie autentycznie przeniknięci Słowem Bożym. Wyrażenie in Scripturis Dominicis eruditi (,wykształceni w Piśmie Pana”) oznacza nie tylko „znających” słowo Boże, ale ukształtowanych tym słowem. To oni w czasach ostatecznych odziedziczą Boże obietnice dane Kościołowi świętemu.

\section{Zobowiązujące miłosierdzie (So 3,10-13)}

Trzeci rozdział Księgi Sofoniasza zawiera obietnicę pocieszenia i naprawy. Bóg okazuje Izraelowi miłosierdzie i przebacza mu jego

92 „Convenite, sociamini, ne cum judicii tempus venerit, et omnis gloria vestra transierit: tunc velitis agere paenitentiam, quando locus non erit poenitentiae, sed poena rum”; tamże. Zwróćmy uwagę na grę słów między paenitentia (,pokuta”) a poena (,kara”).

93 „Reliqui de populo Dei, hoc est, viri ecclesiastici in scripturis dominicis eruditi diripient Eos"; In Sof., ad 2,8-11; CCL 688. 
grzech i niewierność: „I zostawię pośród ciebie lud pokorny i biedny, a szukać będą schronienia w imieniu Pana. Reszta Izraela nie będzie czynić nieprawości ani mówić kłamstwa. I nie znajdzie się w ich ustach zwodniczy język, gdy paść się będą i wylegiwać, a nie będzie nikogo, kto by ich przestraszył" (So 12-12).

Nawiązując do Psalmu 76, 8-11 w tłumaczeniu Wulgaty, ${ }^{94}$ Hieronim wyjaśnia sens tych słów w następujący sposób: „Sądziłem, że wraz z nastaniem Bożego gniewu, porzucił on na wieki grzeszników i powstrzymał swoje miłosierdzie. Zrozumiałem jednak, że stało się to w tym celu, aby odmienił swoją prawicę, prawicę Najwyższego, a dzięki tej odmianie, przemienił wszystko i okazał miłosierdzie tym, których przedtem zgromił. Zatem i my wraz z resztą Izraela, wiedząc, że mamy zdać sprawę z każdego bezużytecznego słowa (Mt 12,36), i że Bóg wytraci wszelkie usta kłamliwe, nie wypowiadajmy rzeczy marnych". ${ }^{95}$

94 „Numquid in aeternum proiciet Deus et non adponet ut conplacitior sit adhuc 9 aut in finem misericordiam suam abscidet a generatione in generationem 10 aut obliviscetur misereri Deus aut continebit in ira sua misericordias suas diapsalma 11 et dixi nunc coepi haec mutatio dexterae Excelsi”. Zwróćmy uwagę, że werset 11 został we Wulgacie (za Septuagintą) przetłumaczony: „I powiedziałem: Teraz rozpocząłem! To jest odmiana prawicy Najwyższego!”, podczas gdy sens tekstu masoreckiego jest następujący: „I powiedziałem: moją udręką jest odmiana prawicy Najwyższego". Różnica wynika z tego, że słowo hallôti, infinitivus constructus czasownika $h$-l-l (,cierpieć udrękę”) z końcówką osobową (,moje bycie udręczonym, moja udręka") zostało odczytane w Septuagincie i Wulgacie jako czasownik od rdzenia $h \square-l-l$ (,,rozpoczynać”) w pierwszej osobie liczby pojedynczej (,rozpocząłem"). W pewnym sensie przekaz Septuaginty i Wulgaty jest przeciwny względem przekazu tekstu masoreckiego: Według pierwszego, karząca prawica Boga odmieniła się we wspomagającą, zaś według drugiego, wspomagająca stała się karzącą. Oba sensy wpisują się w kontekst psalmu.

95 „Hoc quod putabam Dominum in aeternum relinquere peccatores, et misericordias suas ira succedente cohibere, intellexi idcirco factum, ut immutatione dexterae suae, quae excelsi est dextera, universa mutaret, et misereretur his quos ante projecerat. Et nos igitur et reliquiae Israel, scientes quod reddituri sumus rationem pro omni otioso verbo (Mt 12, 36), et quod disperdet Dominus universa labia mendacia, non loquamur vanitatem"; In Sof., ad 3,10-13; CCL 705. 
Zauważmy, że nawrócenie człowieka, do którego zachęca Hieronim w ostatnich słowach zacytowanego fragmentu, wypowiedzianych w pierwszej osobie liczby mnogiej, stanowi w swej istocie naśladowanie Boga. To On pierwszy rezygnuje z wymierzenia kary i ,odmienia swoją prawicę”, aby człowiek porzucił złe czyny nawrócił się do Niego. Zatem uprzedzające miłosierdzie Boga jawi się w interpretacji Hieronima jako wyraz czułości i miłości Najwyższego, zobowiązujący do dania odpowiedzi ze strony Kościoła.

Koniec wyroku i obdarowanie radością (So 3,14-18)

Słowa Sofoniasza: „Wyśpiewuj, Córo Syjońska! Podnieś radosny okrzyk, Izraelu! Ciesz sie i wesel z całego serca, Córo Jeruzalem! Oddalił Pan wyroki na ciebie, usunął twego nieprzyjaciela: król Izraela, Pan, jest pośród ciebie, nie będziesz już bała się złego" (So 3,13-15), zostały w sposób anagogiczny odniesione przez Hieronima do Kościoła w czasach ostatecznych: „Każe cieszyć się Kościołowi i radować Izraelowi, którzy zmysłami doświadczają Boga, a «miejscu pokoju» [tzn. Jerozolimie] świętować i weselić się. Jemu bowiem powiedział: «Pokój mój daję wam, pokój mój zostawiam wam» (J 14,27). Przy końcu bowiem i przy wypełnieniu się świata usunął swój sąd, nie karząc i nie karcąc, ale obdarzając zbawieniem. Ponadto odpędził jego wrogów, to znaczy hordy demonów". ${ }^{96}$

Użyciem czterech synonimicznych czasowników (laudare, jubilare, exsultare, laetari) Hieronim podkreśla atmosferę radości towarzyszącą czasom ostatecznym. Nie jest to już przerażający Harmagedon, dzień Bożego gniewu eksponowany w kantyku Dies Irae, ale zjednoczenie z Bogiem i między sobą, kiedy we wzajemnej miłości Kościół i Izrael doświadczać będą obecności Najwyższego

96 „Laudare jubetur Ecclesia et jubilare Israel, sensu videns Deum, et exsultare atque laetari in omni corde locus pacis, ad quem dictum est: Pacem meam do vobis, pacem meam relinquo vobis $(\mathrm{J} 14,27)$. Abstulit enim in fine et in consummatione mundi judicium ejus, nequaquam eam judicans atque corripiens, sed salvans: et avertit inimicos ejus, daemonum turbas"; In Sof., ad 3,14-18; CCL 707. 
w eschatologicznym Jeruzalem, zapowiedzianym w Księdze Apokalipsy (Ap 21). Triumf ten łączy się nie z pokonaniem ziemskich nieprzyjaciół, ale demonów, w myśl nauczania św. Pawła z Ef 6,12: „Nie toczymy bowiem walki przeciw krwi i ciału, lecz przeciw Zwierzchnościom, przeciw Władzom, przeciw rządcom świata tych ciemności, przeciw pierwiastkom duchowym zła na wyżynach niebieskich".

Obietnica wiecznej chwały (So 3,19-20)

Ostatnie słowa Księgi Sofoniasza brzmią: „Oto Ja sprawię zagładę wszystkim, którzy cię uciskali w owym czasie, a zachowam chromych i wygnanych zgromadzę; i zgotuję z nich chwałę i sławę na całej ziemi, gdzie doznawali zawstydzenia. W owym czasie was przywiodę, w czasie, gdy was zgromadzę; albowiem dam wam imię i chwałę u wszystkich narodów ziemi, gdy odmienię wasz los na waszych oczach - mówi Pan" (So 3,19-20).

Również i ten passus został odczytany przez Hieronima w kluczu eschatologicznym: „Pan podźwignie przy końcu tę, która wydawała się być porzuconą wskutek pokus. Obdarzy chwałą i da imię sławne na całej ziemi synom uciśnionej i odtrąconej, czyli Kościoła". ${ }^{97}$ Do motywu radości eschatologicznej został dołączony motyw chwały i wywyższenia, którego doświadczą wierni Kościoła w czasach ostatecznych.

$$
* * *
$$

Napisany ponad półtora tysiąca lat temu komentarz św. Hieronima do Księgi Sofoniasza zawiera oczywiście liczne interpretacje, które z perspektywy wieków straciły na aktualności. Dotyczy to zwłaszcza pewnych passusów o wydźwięku antyżydowskim.

97 „Eam igitur quae in tentationibus videbatur abjecta, suscipiet Dominus in fine: et ponet eos in gloriam et nominatos in universa terra, filios videlicet expressae et repulsae, id est, Ecclesiae"; In Sof., ad 3,19-20; CCL 710. 
Jednak wydaje się, że liczne treści są wciąż aktualne. Możemy zaliczyć do nich postrzeganie Kościoła jako świętej tajemnicy obecności Boga pośród swojego ludu, ale jednocześnie złożonej z grzesznych ludzi, którymi nawet na wyższych szczeblach hierarchii kieruje pycha, chciwość i żądza władzy.

Jednak Kościół ten otaczany jest czułością i obdarzany miłosierdziem, o którym papież Franciszek wielokrotnie mówi jako o „nieskończonym i bezwarunkowym”, przez samego Jezusa Chrystusa, który ustawicznie wzywa go do nawrócenia i zapewnia o miłości, która w pełni okaże się w radości i chwale czasów ostatecznych.

ks. Krzysztof BARDSKI

Słowa kluczowe: Księga Sofoniasza, Komentarz do Księgi Sofoniasza św. Hieronima, Kościół, grzech, Chrystus

Keywords: Book of Zephaniah, Jerome's Commentary to Zephaniah, the Church, sin, Christ

\section{Christ's Care for the Sinful Church in the Commentary of Jerome to Zephaniah} Summary

The first part of the article presents the allegorical interpretation of several passages connected with the sins of the members of the Church according to the Commentary of St. Jerome to the prophet Zephaniah: a. The vain glory and false dignity of priests and bishops (Zeph 1:4); b. The abandonment of Christ's garments (Zeph 1:8); c. Disrespect for baptism and penance (Zeph 1:10); d. Oppression due to false doctrines (Zeph 1:11, 2:8); e. Sins committed by the representatives of the Church (Zeph 2:9); f. False Christians inside the Church (Zeph 2:14); g. Oppressive superiors (Zeph 3:3); h. Church doctors disregarding the Holy Spirit and the goodness of God. In the second part, the author explores the passages allegorically interpreted in relation to the care of Christ for his beloved Church: a. The light of the word and wisdom (Zeph 1:12); b. Destruction of perverse structures (Zeph 1:13); 
c. An invitation to communion in love and peace (Zeph 2:1); d. The "Rest" of those who know the Word of God (Zeph 2:9); e. Commitment to mercy (Zeph 3:10-13); f. The end of the punishment and the gift of joy (Zeph 3:1418); g. The promise of eternal glory (Zeph 3:19-20). 